\title{
Morphological and germination response variability in seeds of wild yellow gentian (Gentiana lutea L.) accessions from northwest Spain
}

\author{
Félix Pérez-García, Federico Varela, and M. Elena González-Benito
}

\begin{abstract}
Gentiana lutea L. (yellow gentian, Gentianaceae) is an important medicinal plant under protection as endangered species in most European countries. The aim of this work was to evaluate variation in seed mass, seed water content, and seed germination among 56 wild accessions of $G$. lutea. The effect of gibberellic acid (GA3), putrescine, moist chilling, and level of ripeness of seeds on subsequent germination was also investigated. Seeds of $G$. lutea showed physiological dormancy (final germination percentages ranged from $0 \%$ to $11 \%$, depending on the accession) and GA 3 enhanced seed germination drastically in all the accessions. The highest germination (99\%) of $\mathrm{GA}_{3}$-treated seeds was reached at $15{ }^{\circ} \mathrm{C}$. Final germination percentage and germination rate (as expressed by mean germination time), as well as seed mass and seed water content, varied significantly among accessions. In general, 1 year moist chilling did not significantly enhance $G$. lutea seed germination. For most accessions, no significant differences were found between fully ripe seeds and less ripe seeds for seed water content, seed mass, and seed germination. Applications of $\mathrm{GA}_{3}$ were always most effective than those of putrescine for increasing seed germination.
\end{abstract}

Key words: Gentiana lutea, gibberellic acid, physiological dormancy, putrescine, seed germination.

Résumé : Le Gentiana lutea L. (gentiane jaune, Gentinaceae) constitue une importante plante médicinale protégée en tant qu'espèce menacée, dans la plupart des pays d'Europe. Les auteurs ont cherché à évaluer la variation du poids des graines et la germination des graines au sein de 56 accessions du $G$. lutea. Ils ont également examiné les effets de l'acide gibbérellique $\left(\mathrm{GA}_{3}\right)$, de la putrescine, du froid humide, et du degré de maturité des graines sur la germination subséquente. Les graines du G. lutea montrent une dormance physiologique (le pourcentage final de germination allant de $0 \%$ à $11 \%$, selon l'accession) et la $\mathrm{GA}_{3}$ stimule fortement la germination chez toutes les accessions. On a obtenu le plus fort taux de germination à $15{ }^{\circ} \mathrm{C}$ avec des graines traitées par la $\mathrm{GA}_{3}$. Le pourcentage final de germination et le taux de germination (exprimé par le temps moyen de germination), ainsi que le poids des graines et leur teneur en eau, varient significativement selon les accessions. En général, 1 année de froid humide n'augmente pas significativement la germination des graines du $G$. lutea. Chez la plupart des accessions, on n'observe aucune différence significative entre les graines pleinement matures, et les graines moins mûres, quant à la teneur en eau ainsi que le poids et la germination des graines. Les applications de la GA $\mathrm{G}_{3}$ demeurent toujours plus efficaces que celles de la putrescine pour augmenter la germination des graines.

Mots-clés : Gentiana lutea, acide gibbérellique, dormance physiologique, putrescine, germination des graines.

\section{Introduction}

The family Gentianaceae is a cosmopolitan group of 87 genera and more than 1600 species widely distributed throughout the world (Struwe and Albert 2002). Gentiana L., comprising ca. 360 species, is the largest genus in this family. Most Gentiana species are found in temperate and alpine regions of the world (Struwe and Albert 2002). Gentiana lutea $\mathrm{L}$. (yellow gentian or bitterwort) grows in alpine and sub-alpine pastures of central and southern Europe, usually on calcareous soils. This species is under protection as an endangered plant in most European countries due to the uncontrolled use of its roots for bitter glucosides extraction (Momčilović et al. 1997). Yellow gentian wild populations from Spain continue to be exploited for commercial uses, which has led to its decline in some areas. Traditional harvesting of gentian roots implies large recovery periods for wild populations. Gentiana lutea has legal protected status in several autonomous communities of Spain (Andalucía, Aragón, Asturias, Castilla-La Mancha, Castilla-León, Extremadura, Madrid, and País Vasco).

Gentiana lutea has a high medicinal value for the intensely 
bitter properties residing mainly in the root, being the main vegetable bitter employed in homeopathy. Gentian root is a rich source of bitter glycosides such as gentiopikrin and amarogencine (the natural most bitter compound known), which has been used since ancient times for the production of bitter tonics in natural pharmacy and for liqueurs. Yellow gentian is an astringent, cleaning, anti-inflammatory, and gastric stimulant herb that also lowers fever (Mikula and Rybczyński 2001; Struwe and Albert 2002; Raina et al. 2003). This species also has an increasing importance in the beverage industry and it is of great value in gardening because of the beauty of their yellow flowers. The conservation of genetic resources of medicinal plants has been of increasing interest (Bettencourt 1998). Gentiana lutea is in immediate need of ex situ conservation. Seed germination is an integral part of ex situ conservation, especially for developing standard viability monitoring protocols and to ensure germplasm regeneration (Bewley and Black 1994).

Most alpine species have dormant seeds, exhibiting mainly physiological dormancy (Baskin and Baskin 2004; Schwienbacher et al. 2011) and some alpine and sub-alpine plants show high variation in germination behavior that is not always attributed to habitat characteristics (Chambers 1989; Giménez-Benavides et al. 2005). Seeds of some temperate Gentianaceae species in soil seed banks may retain their viability for at least 3 years and germinate in spring or early summer (Thompson et al. 1997). However, seeds of several herbaceous Gentiana species from the Alps were classified as having transient soil seed banks, persisting for less than 1 year (Cerabolini et al. 2003). The establishment of correlations between germination traits and morphological traits would contribute to a better understanding of seed dormancy in Gentiana species.

In general, seed germination of Gentianaceae has been shown to be difficult under laboratory conditions (Baskin and Baskin 1998). Cold stratification was reported to increase germination in some species of this family (Simpson and Webb 1980). Underdeveloped embryos have been reported in several species of Gentianaceae (Baskin and Baskin 2005). Seeds of several temperate Gentiana species require a warm, moist period followed by a cold phase before they are able to germinate (Threadgill et al. 1981). Thus, seeds of Gentiana kurroo need cold stratification to enable germination (Raina et al. 2003). Seed germination of several Gentiana species may be promoted by gibberellic acid (Struwe and Albert 2002). Gentiana cerina, and Gentiana corymbifera (Morgan et al. 1997), and Gentiana scabra (Bicknell 1984) seeds required $\mathrm{GA}_{3}$, with maximum concentration $100 \mathrm{mg} \cdot \mathrm{L}^{-1}$, to germinate. However, higher $\mathrm{GA}_{3}$ concentrations suppressed seed germination of these species. In Gentiana cruciata, Gentiana pannonica, and Gentiana tibetica, applications of $\mathrm{GA}_{3}$ decreased seed germination when compared with untreated control seeds (Mikula and Rybczyński 2001). Very little information is available on the seed germination of $G$. lutea. It has been suggested that seeds of this species have a cold stratification requirement for germination (Favarger 1953). Lorite et al. (2007), studying the germination behavior of several species from the Sierra Nevada high mountain (SE Spain), showed that the final germination percentage reached by $G$. lutea seeds without any pretreatment was always lower than $1 \%$.

In this work, useful information on germination character- istics of $G$. lutea is provided. The specific aims of this study were: $(i)$ to investigate if there is morphological (seed mass and seed water content) and physiological (seed germination) variability among wild $G$. lutea accessions; (ii) to analyse if there is any relationship between seed germination of $G$. lutea and traits related either to the seeds (seed mass and seed water content) or to the habitat (altitude of collection site); and (iii) to examine the effect of different incubation temperatures, light conditions, moist chilling, seed ripeness, and plant growth regulators ( $\mathrm{GA}_{3}$ and putrescine) on seed germination of this species. Data on germination conditions of $G$. lutea seeds could be used in ex situ conservation management and propagation of this important medicinal species and could also contribute to the preservation of this species in their natural habitats.

\section{Materials and methods}

\section{Species description}

Gentiana lutea is a hemicryptophyte with erect stems, growing to $0.5-1.7 \mathrm{~m}$ tall, prized for its yellow flowers. Gentian fruits are capsules with winged and elliptic seeds from 2.5 to $5 \mathrm{~mm}$ in length and from 2.5 to $4.5 \mathrm{~mm}$ in width. Seeds have a nonstarchy endosperm and a linear embryo (Akhalkatsi and Wagner 1997). In the Iberian Peninsula, yellow gentian grows in wet meadows, hay meadows, and open woods, mainly in the Pyrenees and the Cantabrian mountains, over approximately $1000 \mathrm{~m}$. Flowering lasts from June to July and maturation occurs from July to August.

\section{Seed collection}

Mature fruits (capsules) of $G$. lutea containing well-developed ripe seeds were sampled from 35 wild growing populations (subpopulations according to IUCN terminology; IUCN 2010) on the mountains of Leon province (northwestern Spain) at altitudes ranging from 1515 to $1945 \mathrm{~m}$ a.s.l. (see Table 1) in September and October 2008. Seeds were taken from at least 10 randomly selected plants in each population. Collected seeds showed a similar degree of ripeness, as observed from their colour and hardness. Seed samples were manually cleaned, eliminating any visually malformed seeds, kept in paper bags, and then stored dry under laboratory conditions (ca. $25^{\circ} \mathrm{C}$ under darkness) until they were used in the germination tests in January 2009. For all sampled populations, visible deficient seeds (less than $5 \%$ of the total collected seeds) were excluded from the experiments.

Similarly, fully ripe seeds (ripe seeds hereinafter) and less ripe seeds (unripe seeds hereinafter) were taken from 21 new populations of the same mountain belt at altitudes between 1396 and $1805 \mathrm{~m}$ a.s.l. (see Table 1) in late August 2009. Although, by the time the experiments were performed ripe and unripe seeds were externally similar, there were differences in the way they were obtained. Ripe seeds were harvested by shaking fully dry mature capsules that were on the plant. Unripe seeds were obtained by excising green closed capsules from the plant, which were left to dry in the laboratory for 1-2 weeks before extracting the seeds. These seeds were cleaned and stored as above until the start of the germination trials in December 2009. For each population, seeds belonging to at least 10 individual plants were bulked. 
Table 1. Sampling year of seeds, geographical parameters (altitude, latitude, and longitude) of collection site, seed water content (fwb), seed mass (per 100 seeds), and final germination percentage for 56 Gentiana lutea populations located in León province (northwestern Spain).

\begin{tabular}{|c|c|c|c|c|c|c|c|c|}
\hline Accession & $\begin{array}{l}\text { Collection } \\
\text { year }\end{array}$ & $\begin{array}{l}\text { Altitude } \\
\text { (m a.s.1.) }\end{array}$ & $\begin{array}{l}\text { Latitude } \\
\text { (N) }\end{array}$ & $\begin{array}{l}\text { Longitude } \\
\text { (W) }\end{array}$ & $\begin{array}{l}\text { Seed water content } \\
(\mathrm{fwb})(\% \pm \mathrm{SE})\end{array}$ & $\begin{array}{l}\text { Mass of } 100 \\
\text { seeds }(\mathrm{mg} \pm \mathrm{SE})\end{array}$ & \multicolumn{2}{|c|}{ Germination $(\% \pm \mathrm{SE})$} \\
\hline 2 & 2009 & 1414 & $42^{\circ} 58^{\prime} 01^{\prime \prime}$ & $6^{\circ} 19^{\prime} 50^{\prime \prime}$ & $5.38 \pm 0.04$ & $109.85 \pm 3.85$ & 0 & $86 \pm 2.47$ \\
\hline 3 & 2009 & 1456 & $42^{\circ} 58^{\prime} 59^{\prime \prime}$ & $6^{\circ} 28^{\prime} 15^{\prime \prime}$ & $5.74 \pm 0.07$ & $89.00 \pm 0.35$ & 0 & $85 \pm 0.35$ \\
\hline 4 & 2008 & 1515 & $42^{\circ} 55^{\prime} 06^{\prime \prime}$ & $6^{\circ} 24^{\prime} 55^{\prime \prime}$ & $5.17 \pm 0.12$ & $92.70 \pm 0.57$ & 0 & $65 \pm 4.95$ \\
\hline 7 & 2009 & 1565 & $42^{\circ} 56^{\prime} 14^{\prime \prime}$ & $6^{\circ} 24^{\prime} 38^{\prime \prime}$ & $4.90 \pm 0.13$ & $91.95 \pm 3.99$ & $1 \pm 0.71$ & $94 \pm 0.00$ \\
\hline 8 & 2008 & 1575 & $41^{\circ} 48^{\prime} 16^{\prime \prime}$ & $6^{\circ} 21^{\prime} 33^{\prime \prime}$ & $4.50 \pm 0.09$ & $98.90 \pm 1.27$ & $1 \pm 0.71$ & $98 \pm 1.41$ \\
\hline 9 & 2009 & 1592 & $43^{\circ} 00^{\prime} 07^{\prime \prime}$ & $6^{\circ} 18^{\prime} 07^{\prime \prime}$ & $5.39 \pm 0.19$ & $115.75 \pm 1.87$ & 0 & $90 \pm 0.35$ \\
\hline 10 & 2009 & 1598 & $42^{\circ} 59^{\prime} 43^{\prime \prime}$ & $6^{\circ} 05^{\prime} 30^{\prime \prime}$ & $4.86 \pm 0.15$ & $110.30 \pm 1.56$ & 0 & $88 \pm 2.83$ \\
\hline 11 & 2009 & 1604 & $42^{\circ} 48^{\prime} 17^{\prime \prime}$ & $6^{\circ} 10^{\prime} 32^{\prime \prime}$ & $5.08 \pm 0.09$ & $134.50 \pm 2.54$ & 0 & $98 \pm 1.06$ \\
\hline 12 & 2008 & 1605 & $42^{\circ} 53^{\prime} 35^{\prime \prime}$ & $6^{\circ} 28^{\prime} 46^{\prime \prime}$ & $4.42 \pm 0.05$ & $94.35 \pm 0.60$ & 0 & $87 \pm 2.12$ \\
\hline 16 & 2009 & 1635 & $42^{\circ} 48^{\prime} 52^{\prime \prime}$ & $6^{\circ} 10^{\prime} 57^{\prime \prime}$ & $5.17 \pm 0.19$ & $150.00 \pm 2.12$ & 0 & $93 \pm 4.95$ \\
\hline 17 & 2009 & 1637 & $42^{\circ} 58^{\prime} 35^{\prime \prime}$ & $6^{\circ} 17^{\prime} 13^{\prime \prime}$ & $4.60 \pm 0.09$ & $105.35 \pm 4.21$ & 0 & $88 \pm 3.53$ \\
\hline 18 & 2008 & 1639 & $42^{\circ} 48^{\prime} 45^{\prime \prime}$ & $6^{\circ} 19^{\prime} 19^{\prime \prime}$ & $5.12 \pm 0.12$ & $112.10 \pm 0.78$ & $4 \pm 1.41$ & $98 \pm 1.41$ \\
\hline 19 & 2008 & 1639 & $42^{\circ} 51^{\prime} 28^{\prime \prime}$ & $6^{\circ} 16^{\prime} 59^{\prime \prime}$ & $4.34 \pm 0.01$ & $94.40 \pm 1.91$ & $1 \pm 0.71$ & $92 \pm 1.41$ \\
\hline 20 & 2008 & 1645 & $42^{\circ} 53^{\prime} 05^{\prime \prime}$ & $6^{\circ} 10^{\prime} 30^{\prime \prime}$ & $4.44 \pm 0.03$ & $108.05 \pm 0.67$ & $9 \pm 0.71$ & $95 \pm 2.12$ \\
\hline 21 & 2008 & 1657 & $42^{\circ} 52^{\prime} 09^{\prime \prime}$ & $6^{\circ} 22^{\prime} 12^{\prime \prime}$ & $4.84 \pm 0.03$ & $119.70 \pm 3.61$ & $2 \pm 1.41$ & $89 \pm 2.12$ \\
\hline 22 & 2008 & 1663 & $42^{\circ} 53^{\prime} 52^{\prime \prime}$ & $6^{\circ} 29^{\prime} 01^{\prime \prime}$ & $5.03 \pm 0.01$ & $101.40 \pm 1.70$ & $4 \pm 1.41$ & $92 \pm 2.83$ \\
\hline 23 & 2008 & 1676 & $42^{\circ} 53^{\prime} 22^{\prime \prime}$ & $6^{\circ} 10^{\prime} 37^{\prime \prime}$ & $4.27 \pm 0.07$ & $111.15 \pm 2.37$ & 0 & $83 \pm 4.95$ \\
\hline 24 & 2009 & 1678 & $43^{\circ} 02^{\prime} 04^{\prime \prime}$ & $6^{\circ} 11^{\prime} 07^{\prime \prime}$ & $5.24 \pm 0.00$ & $85.85 \pm 1.38$ & 0 & $90 \pm 1.77$ \\
\hline 25 & 2009 & 1688 & $42^{\circ} 49^{\prime} 09^{\prime \prime}$ & $6^{\circ} 10^{\prime} 57^{\prime \prime}$ & $5.88 \pm 0.06$ & $134.40 \pm 0.21$ & 0 & $80 \pm 2.12$ \\
\hline 26 & 2009 & 1691 & $42^{\circ} 59^{\prime} 38^{\prime \prime}$ & $6^{\circ} 18^{\prime} 54^{\prime \prime}$ & $5.47 \pm 0.07$ & $84.95 \pm 0.53$ & 0 & $85 \pm 1.77$ \\
\hline 27 & 2009 & 1692 & $42^{\circ} 59^{\prime} 37^{\prime \prime}$ & $6^{\circ} 25^{\prime} 07^{\prime \prime}$ & $5.85 \pm 0.11$ & $74.20 \pm 1.98$ & 0 & $74 \pm 2.83$ \\
\hline 35 & 2008 & 1732 & $42^{\circ} 50^{\prime} 16^{\prime \prime}$ & $6^{\circ} 11^{\prime} 48^{\prime \prime}$ & $4.89 \pm 0.16$ & $104.05 \pm 1.59$ & $2 \pm 1.41$ & $91 \pm 0.71$ \\
\hline 36 & 2008 & 1740 & $42^{\circ} 52^{\prime} 16^{\prime \prime}$ & $6^{\circ} 22^{\prime} 52^{\prime \prime}$ & $5.19 \pm 0.02$ & $127.95 \pm 0.18$ & $2 \pm 0.00$ & $91 \pm 0.71$ \\
\hline 37 & 2009 & 1746 & $42^{\circ} 47^{\prime} 13^{\prime \prime}$ & $6^{\circ} 12^{\prime} 30^{\prime \prime}$ & $5.41 \pm 0.24$ & $128.75 \pm 1.24$ & 0 & $96 \pm 2.47$ \\
\hline 38 & 2008 & 1751 & $42^{\circ} 54^{\prime} 50^{\prime \prime}$ & $6^{\circ} 29^{\prime} 11^{\prime \prime}$ & $5.52 \pm 0.01$ & $95.10 \pm 0.85$ & 0 & $87 \pm 3.53$ \\
\hline 39 & 2008 & 1762 & $42^{\circ} 54^{\prime} 52^{\prime \prime}$ & $6^{\circ} 27^{\prime} 07^{\prime \prime}$ & $5.39 \pm 0.14$ & $101.95 \pm 0.11$ & 0 & $89 \pm 4.95$ \\
\hline 40 & 2009 & 1762 & $42^{\circ} 53^{\prime} 48^{\prime \prime}$ & $6^{\circ} 20^{\prime} 10^{\prime \prime}$ & $5.34 \pm 0.17$ & $100.00 \pm 2.40$ & 0 & $86 \pm 0.71$ \\
\hline 41 & 2008 & 1785 & $42^{\circ} 51^{\prime} 24^{\prime \prime}$ & $6^{\circ} 14^{\prime} 20^{\prime \prime}$ & $4.87 \pm 0.16$ & $115.70 \pm 1.27$ & 0 & $98 \pm 1.41$ \\
\hline 42 & 2008 & 1794 & $42^{\circ} 52^{\prime} 13^{\prime \prime}$ & $6^{\circ} 23^{\prime} 06^{\prime \prime}$ & $5.51 \pm 0.13$ & $94.25 \pm 1.59$ & $2 \pm 1.41$ & $86 \pm 2.83$ \\
\hline 43 & 2008 & 1800 & $43^{\circ} 00^{\prime} 50^{\prime \prime}$ & $6^{\circ} 06^{\prime} 50^{\prime \prime}$ & $4.94 \pm 0.30$ & $111.35 \pm 0.46$ & 0 & $93 \pm 3.53$ \\
\hline 44 & 2008 & 1801 & $43^{\circ} 00^{\prime} 47^{\prime \prime}$ & $6^{\circ} 06^{\prime} 35^{\prime \prime}$ & $5.69 \pm 0.04$ & $98.35 \pm 0.74$ & 0 & $81 \pm 3.53$ \\
\hline 45 & 2009 & 1805 & $42^{\circ} 55^{\prime} 23^{\prime \prime}$ & $6^{\circ} 06^{\prime} 03^{\prime \prime}$ & $5.40 \pm 0.01$ & $98.20 \pm 1.56$ & 0 & $94 \pm 0.00$ \\
\hline 46 & 2008 & 1822 & $42^{\circ} 53^{\prime} 18^{\prime \prime}$ & $6^{\circ} 11^{\prime} 03^{\prime \prime}$ & $6.63 \pm 0.01$ & $102.55 \pm 0.53$ & 0 & $96 \pm 2.83$ \\
\hline 47 & 2008 & 1824 & $42^{\circ} 52^{\prime} 18^{\prime \prime}$ & $6^{\circ} 23^{\prime} 32^{\prime \prime}$ & $4.40 \pm 0.03$ & $102.15 \pm 0.74$ & 0 & $91 \pm 4.95$ \\
\hline 48 & 2008 & 1847 & $42^{\circ} 52^{\prime} 24^{\prime \prime}$ & $6^{\circ} 17^{\prime} 57^{\prime \prime}$ & $4.85 \pm 0.02$ & $89.70 \pm 1.13$ & 0 & $97 \pm 2.12$ \\
\hline 49 & 2008 & 1849 & $42^{\circ} 52^{\prime} 06^{\prime \prime}$ & $6^{\circ} 17^{\prime} 27^{\prime \prime}$ & $4.37 \pm 0.09$ & $127.70 \pm 3.89$ & $8 \pm 4.24$ & $99 \pm 0.71$ \\
\hline 50 & 2208 & 1850 & $42^{\circ} 51^{\prime} 53^{\prime \prime}$ & $6^{\circ} 17^{\prime} 33^{\prime \prime}$ & $4.30 \pm 0.13$ & $123.10 \pm 0.49$ & $7 \pm 3.53$ & $94 \pm 2.83$ \\
\hline 51 & 2008 & 1850 & $42^{\circ} 52^{\prime} 25^{\prime \prime}$ & $6^{\circ} 17^{\prime} 28^{\prime \prime}$ & $4.79 \pm 0.03$ & $127.35 \pm 0.74$ & 0 & $97 \pm 2.12$ \\
\hline 52 & 2008 & 1866 & $43^{\circ} 00^{\prime} 09^{\prime \prime}$ & $6^{\circ} 05^{\prime} 07^{\prime \prime}$ & $4.84 \pm 0.05$ & $100.15 \pm 1.10$ & $1 \pm 0.71$ & $99 \pm 0.71$ \\
\hline 53 & 2008 & 1897 & $42^{\circ} 49^{\prime} 21^{\prime \prime}$ & $6^{\circ} 19^{\prime} 18^{\prime \prime}$ & $5.33 \pm 0.05$ & $102.35 \pm 2.93$ & $3 \pm 0.71$ & $96 \pm 1.41$ \\
\hline 54 & 2008 & 1900 & $42^{\circ} 52^{\prime} 52^{\prime \prime}$ & $6^{\circ} 18^{\prime} 27^{\prime \prime}$ & $4.61 \pm 0.03$ & $125.60 \pm 0.67$ & $7 \pm 0.71$ & $93 \pm 2.12$ \\
\hline
\end{tabular}


Table 1 (concluded).

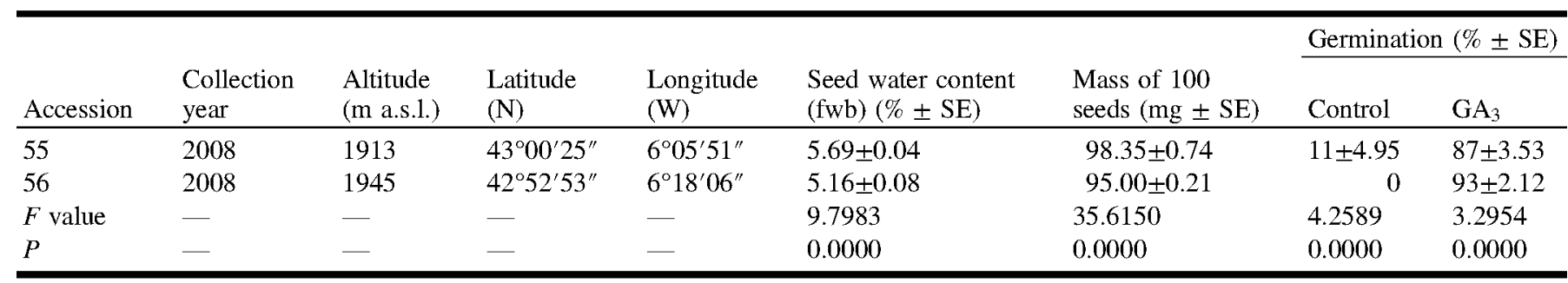

Note: $P$, for each column signifies significant differences among accessions. Seeds were soaked for $24 \mathrm{~h}$ in distilled water (control) or in a gibberellic acid solution $\left(\mathrm{GA}_{3}, 1000 \mathrm{mg} \cdot \mathrm{L}^{-1}\right)$ before being germinated. Germination percentage values are mean \pm standard error $(n=4)$ after 75 days of seed incubation at

$15^{\circ} \mathrm{C}$ under a 16-h light photoperiod. Accessions are ranked by increasing altitude of collection site.

\section{Water uptake during seed imbibition}

To determine water uptake capacity during seed imbibition, two sets of ca. 200 seeds each from two accessions (numbers 41 and 52; see Table 1) were weighed and then placed in Petri dishes on moist filter papers. After 24, 48, and $72 \mathrm{~h}$, seeds were taken out of the Petri dishes, quickly surface-dried with filter paper, reweighed, and returned to the dishes. Water uptake percentage was calculated as the amount of water taken up relative to initial seed fresh mass.

\section{General seed germination trials}

In all trials carried out, seeds were soaked at room temperature for $24 \mathrm{~h}$ in distilled water (control seeds) or in a gibberellic acid water solution $\left(\mathrm{GA}_{3}, 1000 \cdot \mathrm{mg} \mathrm{L}^{-1}\right)$ before sowing. Four replicates of 25 seeds each or two replicates of 35 seeds each (depending on the trial) were tested for germination on top of two sheets of filter paper (previously moistened with $3.5 \mathrm{~mL}$ distilled water) in $7 \mathrm{~cm}$ diameter glass Petri dishes. Filter papers were rewetted regularly with distilled water as required. Dishes were checked three times a week over a 75day test period and germinated seeds were counted and removed. Seeds were regarded as germinated when the length of the radicle exceeded $1 \mathrm{~mm}$ from the seed coat. In all trials carried out, at the end of the incubation period, ungerminated seeds were checked by cutting open each seed and the number of empty seeds was recorded (ISTA 2003).

\section{Effect of temperature and light regimes on seed germination}

The aim of this experiment was to determine the optimal temperature and light requirements for radicle emergence. Germination of seeds belonging to the accessions 41 and 52 collected in 2008 were tested at different constant temperatures $\left(10^{\circ} \mathrm{C}, 15^{\circ} \mathrm{C}, 20^{\circ} \mathrm{C}\right.$, and $\left.25^{\circ} \mathrm{C}\right)$ with a 16 -h light photoperiod (provided by cool white fluorescent tubes with an irradiance of $\left.35 \mu \mathrm{mol} \cdot \mathrm{m}^{-2} \cdot \mathrm{s}^{-1}\right)$ and the alternate temperatures of $25 / 15^{\circ} \mathrm{C}\left(25^{\circ} \mathrm{C}\right.$ for $16 \mathrm{~h}$ light and $15{ }^{\circ} \mathrm{C}$ for $8 \mathrm{~h}$ dark incubation). These two accessions were chosen because of the large quantity of collected seeds. Four replicates of 25 seeds each were used in all these trials. Before sowing, seeds incubated at $25^{\circ} \mathrm{C}$ and $25 / 15^{\circ} \mathrm{C}$ were surface-sterilized for $5 \mathrm{~min}$ with $10 \%$ sodium hypochlorite and then rinsed three times with distilled water. In addition, seeds belonging to these two accessions were tested for germination at $15^{\circ} \mathrm{C}$ under constant darkness. Darkness treatment was obtained by wrapping Petri dishes in a double layer of aluminium foil. A green safe light (Baskin and Baskin 1998) was used to examine the germination response in dark-incubated seeds. As above, four replicates of 25 seeds each were used.

\section{Variability in seed water content, seed mass, and seed germination among accessions}

Germination of seeds belonging to 56 accessions collected in 2008 and 2009 were tested at $15^{\circ} \mathrm{C}$ under a 16-h light photoperiod. Seeds were soaked for $24 \mathrm{~h}$ in distilled water or in a gibberellic acid water solution $\left(\mathrm{GA}_{3}, 1000 \mathrm{mg} \cdot \mathrm{L}^{-1}\right)$ before sowing. Four replicates of 25 seeds each were used in these trials. At the end of germination period ungerminated $\mathrm{GA}_{3}$-treated seeds, of those accessions whose germination was $<85 \%$, were dissected longitudinally and medially through the embryo with a scalpel and then they were soaked in $1 \%$ 2,3,5-triphenyl tetrazolium chloride solution for $24 \mathrm{~h}$ at $25{ }^{\circ} \mathrm{C}$ in the dark. Embryos that were uniformly and completely stained red were assessed as being viable.

Two replicates of 200 seeds each belonging to the different accessions were used to quantify seed mass (mg). The initial seed water content was determined using the high temperature oven method $\left(130{ }^{\circ} \mathrm{C}\right.$ for $1 \mathrm{~h}$; ISTA 2003) with two replicates of 200 seeds each. Water content was expressed as a percentage on a fresh mass basis (fmb). Seed mass and seed water content were determined immediately before carrying out the germination trials.

\section{Effect of moist chilling on seed germination}

The effect of a chilling (so-called cold stratification) pretreatment of fully imbibed seeds was tested by maintaining sets of 150 seeds per accession (35 accessions collected in $2008)$ at $5 \pm 1{ }^{\circ} \mathrm{C}$ in glass Petri dishes $(9 \mathrm{~cm}$ diameter) with two sheets of filter paper moistened with distilled water. Seeds were cold stratified in November 2008. Moist chilling was carried out under constant darkness by wrapping Petri dishes in a double layer of aluminium foil. Dishes were checked once a month over a total of 1 year chilling period and filter papers were rewetted with distilled water as required. After the stratification period, seeds were soaked for $24 \mathrm{~h}$ in distilled water (control seeds) or in a $\mathrm{GA}_{3}$ solution (1000 $\mathrm{mg} \cdot \mathrm{L}^{-1}$ ) before being set to germinate. Two replicates of 35 seeds each per accession were sown as above (see "general seed germination trials") and incubated at $15{ }^{\circ} \mathrm{C}$ under a 16-h light photoperiod. Besides, seeds belonging to the accessions 41 and 52 were subjected to cold stratification for different periods shorter than 1 year; 1 week and 1,3 , and 6 months. After each period, seeds were set to germinate as above. In this last trial, only untreated seeds (control seeds) were sown. 
Seed water content, seed mass, and seed germination of ripe and unripe seeds

Seed water content and seed mass of ripe and unripe seeds belonging to 21 accessions collected in 2009 were determined as above. To assess the effect of seed maturity on germination behavior, ripe and unripe seeds (two replicates of 35 seeds each per accession) were sown as above (see general seed germination trials) and incubated at $15^{\circ} \mathrm{C}$ under a 16-h light photoperiod.

\section{Effect of seed presoaking in several concentrations of $\mathrm{GA}_{3}$ and putrescine}

Seeds from accessions 41 and 52 were soaked for $24 \mathrm{~h}$ in several water solutions of $\mathrm{GA}_{3}$ and putrescine before sowing. The following concentrations of $\mathrm{GA}_{3}$ and putrescine were tested: $10,50,100,250,500$, and $1000 \mathrm{mg} \cdot \mathrm{L}^{-1}$. After treatments, four replicates of 25 seeds each were sowed as above (see general seed germination trials) and incubated at $15{ }^{\circ} \mathrm{C}$ under a 16-h light photoperiod.

\section{Data analysis}

At the end of the incubation period (75 days), the final germination percentage (mean value \pm standard error) and the mean germination time (MGT, mean value in days \pm standard error) were calculated. The latter was determined according to the following formula (Ellis and Roberts 1981): MGT $=\Sigma \mathrm{DN} / \Sigma \mathrm{N}$; where D is the number of days counted from the date of sowing and $\mathrm{N}$ is the number of seeds germinated on day D. In all trials carried out, infected seeds and empty seeds were always excluded from the calculation of final germination percentages. The values of final germination percentages were arcsine transformed and then subjected to ANOVA (untransformed data appears in the Tables) using the computing package SPSS. One-way factorial ANOVA was carried out to determine differences among germination of seeds belonging to different accessions and to test the effects of the incubation temperatures, light conditions, cold stratification, level of seed ripeness, and concentrations of $\mathrm{GA}_{3}$ and putrescine on seed germination. Where ANOVA indicated a significant effect, a comparison of mean values was carried out through the least significant difference test (LSD) at $5 \%$ level of significance. Statistical analysis of seed mass, seed water content, and MGT values were also carried out using one-way factorial ANOVA.

Correlations among seed germination, seed mass, seed water content, and altitude were calculated by linear regressions. The resulting regressions were tested for differences. The linear regressions were compared using the computing package SPSS and $P<0.05$ was the significance level.

\section{Results}

\section{Variability in seed germination, seed mass, and seed water content among accessions}

Germination of seeds belonging to 56 accessions is shown in Table 1 . Highly significant differences $(P<0.001)$ were found among the different accessions tested for the final germination percentages of untreated seeds (from $0 \%$ to $11 \%$ ) and $\mathrm{GA}_{3}$-treated seeds (from $61 \%$ to $99 \%$ ). Seed dormancy of all $G$. lutea accessions was broken by $\mathrm{GA}_{3}$ (Table 1 ). Germination percentage of untreated seeds was $0 \%$ for 36 accessions
(64.3\% of the accessions tested) while germination of $\mathrm{GA}_{3}-$ treated seeds was equal or higher than $90 \%$ for 37 accessions (66.1\% of the accessions tested). Viability (according to the tetrazolium test) of ungerminated $\mathrm{GA}_{3}$-treated seeds from accessions whose germination was $<85 \%$ (only seven accessions) was very high and ranged from $94 \%$ to $100 \%$.

Seed mass varied significantly $(P<0.001)$ among accessions, with a wide range from 74.20 to $150.00 \mathrm{mg}$ per 100 seeds. Similarly, highly significant differences $(P<0.001)$ were found among the different accessions tested for seed water content (from $3.92 \%$ to $5.88 \%$ ).

Final germination percentage of $\mathrm{GA}_{3}$-treated seeds belonging to 56 accessions did not correlate significantly with the seed water content $\left(r^{2}=0.0675 ; P=0.0531\right)$ nor with the altitude $\left(r^{2}=0.0325 ; P=0.1830\right)$ where population grows (Table 1). However, a slightly significant positive correlation between seed mass and seed germination $\left(r^{2}=0.0827 ; P=\right.$ 0.0316) was found. In general, the accessions with heavier seeds reached higher germination percentages. Seed mass did not correlate significantly with the seed water content $\left(r^{2}=0.0353 ; P=0.1658\right)$ nor with altitude $\left(r^{2}=0.0000\right.$; $P=0.9847$ ). Similarly, no significant relationship was found between seed water content and altitude $\left(r^{2}=0.0003 ; P=\right.$ 0.9044).

\section{Water uptake during seed imbibition}

Gentiana lutea seeds from the two accessions tested imbibed water quickly after soaking for $24 \mathrm{~h}$ in distilled water. Seed mass increase after $24 \mathrm{~h}$ imbibition was $133.6 \% \pm 0.9 \%$ and $139.1 \% \pm 2.0 \%$ of the initial seed mass in accessions 41 and 52 , respectively. By $48 \mathrm{~h}$, seed mass increase was $136.5 \% \pm 5.3 \%$ in accession 41 , and $136.0 \% \pm 4.3 \%$ in accession 52. After $72 \mathrm{~h}$ of imbibition, seed mass increase was $136.6 \% \pm 2.8 \%$ in accession 41 , and $137.8 \% \pm 3.1 \%$ in accession $\overline{52}$.

G.entiana lutea embryos (small and straight in shape) were visually already fully developed in ripe seeds and no embryo growth appears to occur after 72 -h seed imbibition. In all germination trials carried out, embryoless-seed percentage was very low $(<2 \%)$.

\section{Effect of temperature and light conditions on seed germination}

The effect of several incubation temperature regimes on the germination of seeds from two accessions (nos. 41 and 52 ) is shown in Table 2. No significant differences were found among temperatures for the final germination percentages. For all temperatures assayed, no germination was recorded for control seeds (untreated seeds). On the contrary, seeds presoaked in $\mathrm{GA}_{3}$ exhibited very high germination percentages $(78 \%-99 \%$, depending on temperature) in both accessions. The highest germination percentages $(98 \%-99 \%)$ of $\mathrm{GA}_{3}$-treated seeds were reached at $15^{\circ} \mathrm{C}$. Therefore, this temperature $\left(15^{\circ} \mathrm{C}\right)$ was used in all subsequent germination trials. The lowest germination $(78 \%)$ was reached at $25{ }^{\circ} \mathrm{C}$ and $25 / 15{ }^{\circ} \mathrm{C}$. Slightly significant differences $(P<0.05)$ were found between temperatures for the MGT values (13.01-31.65 days). Seeds from both accessions reached similar MGT values at each temperature assayed. Germination was significantly delayed at the lowest temperature assayed $\left(10^{\circ} \mathrm{C}\right)$. 
Table 2. Effect of different temperature incubation regimes on the final germination percentage and mean germination time (MGT, days) of seeds from two Gentiana lutea accessions.

\begin{tabular}{|c|c|c|c|c|c|}
\hline \multirow[b]{2}{*}{ Accession } & \multirow{2}{*}{$\frac{\text { Incubation }}{\text { Temperature }}$} & \multicolumn{2}{|c|}{ Germination $(\% \pm \mathrm{SE})$} & \multicolumn{2}{|c|}{ MGT (days \pm SE) } \\
\hline & & Control & $\mathrm{GA}_{3}$ & Control & $\mathrm{GA}_{3}$ \\
\hline \multirow[t]{5}{*}{41} & $10^{\circ} \mathrm{C}$ & 0 & $92 \pm 1.06 \mathrm{a}$ & nc & $31.65 \pm 0.32 b$ \\
\hline & $15^{\circ} \mathrm{C}$ & 0 & $98 \pm 1.41 \mathrm{a}$ & nc & $17.50 \pm 0.64 \mathrm{a}$ \\
\hline & $20^{\circ} \mathrm{C}$ & 0 & $93 \pm 4.95 a$ & nc & $15.70 \pm 1.56 \mathrm{a}$ \\
\hline & $25{ }^{\circ} \mathrm{C}$ & 0 & $80 \pm 0.00 \mathrm{a}$ & $\mathrm{nc}$ & $14.45 \pm 0.11 \mathrm{a}$ \\
\hline & $25 / 15^{\circ} \mathrm{C}$ & 0 & $78 \pm 1.06 \mathrm{a}$ & nc & $18.25 \pm 0.32 \mathrm{a}$ \\
\hline \multirow[t]{5}{*}{52} & $10^{\circ} \mathrm{C}$ & $0 \mathrm{a}$ & $94 \pm 2.12 \mathrm{a}$ & nc & $31.75 \pm 0.81 \mathrm{c}$ \\
\hline & $15^{\circ} \mathrm{C}$ & $1 \pm 0.7 \mathrm{a}$ & $99 \pm 0.71 \mathrm{a}$ & $\mathrm{nc}$ & $16.30 \pm 0.28 b$ \\
\hline & $20^{\circ} \mathrm{C}$ & $0 \mathrm{a}$ & $93 \pm 4.95 \mathrm{a}$ & $\mathrm{nc}$ & $14.40 \pm 0.21 \mathrm{ab}$ \\
\hline & $25^{\circ} \mathrm{C}$ & $0 \mathrm{a}$ & $78 \pm 3.18 \mathrm{a}$ & $\mathrm{nc}$ & $13.01 \pm 0.49 \mathrm{a}$ \\
\hline & $25 / 15^{\circ} \mathrm{C}$ & $0 \mathrm{a}$ & $78 \pm 1.06 \mathrm{a}$ & $\mathrm{nc}$ & $14.80 \pm 0.56 \mathrm{ab}$ \\
\hline
\end{tabular}

Note: nc, MGT value was not calculated when germination percentage was equal to or less than $5 \%$. Mean values followed by the same letters in a column per each population are not significantly different $(P>0.05)$ according to LSD test. Seeds were soaked for $24 \mathrm{~h}$ in distilled water (control) or in a gibberellic acid solution $\left(\mathrm{GA}_{3}, 1000 \mathrm{mg} \cdot \mathrm{L}^{-1}\right)$ before being germinated. Values are mean \pm standard error $(n$ $=4$ ) after 75 days of seed incubation under a 16-h light photoperiod.

The effect of light conditions on germination was studied for seeds belonging to those two accessions. Final germination percentages reached under a 16-h light photoperiod and complete darkness were very similar (Table 3 ). Germination percentages were not significantly affected by light conditions. Similarly, no significant differences were found between photoperiod and darkness for the MGT values. However, the seeds from both accessions reached lower MGT values under photoperiod than under constant darkness. Therefore, photoperiod conditions were used in all subsequent assays.

\section{Effect of moist chilling on seed germination}

In general, moist chilling did not affect seed germination (Table 4). For control seeds (seeds not treated with $\mathrm{GA}_{3}$ ) there was no significant difference among germination percentages for nonchilled and chilled seeds for most accessions tested. Chilling significantly $(P<0.05)$ enhanced the final germination percentages of untreated seeds only in 2 of the 35 accessions tested. For $\mathrm{GA}_{3}$-treated seeds, chilling did not significantly enhance germination percentage in any of the accessions tested. No significant differences $(P=0.2518)$ were found among accessions for final germination percentages reached by chilled seeds for seeds presoaked in $\mathrm{GA}_{3}$ (Table 4). Chilling did not increase the germination rate in any of the accessions tested. The lowest MGT values (the highest speed of germination) of $\mathrm{GA}_{3}$-treated seeds were always attained by nonchilled seeds (Table 5), and in 13 of the 35 accessions ( $37 \%$ of the accessions tested) these differences were significant $(P<0.05)$. For seeds presoaked in $\mathrm{GA}_{3}$, highly significant differences $(P<0.001)$ were found among the different accessions tested for MGT values of nonchilled seeds (from 14.20 to 23.25 days) and chilled seeds (from 16.80 to 35.60 days). For chilled seeds from accessions 41 and 52, no germination was recorded after all chilling periods assayed (1 week and 1,3, and 6 months).

\section{Effect of seed ripeness on seed germination}

Table 6 shows the seed water content, seed mass, and seed germination of ripe and unripe seeds belonging to 21 accessions. Seeds were previously soaked for $24 \mathrm{~h}$ in a $\mathrm{GA}_{3}$ solu- tion of $1000 \mathrm{mg} \cdot \mathrm{L}^{-1}$. For most accessions, no significant differences were found between ripe and unripe seeds for seed water content, seed mass, and final germination percentage. Only in 1 of the 21 accessions tested, the seed water content of unripe seeds was significantly $(P<0.05)$ higher than that of ripe seeds. For eight accessions, nonripened seeds were significantly $(P<0.05)$ heavier than ripe seeds. For four accessions, unripe seeds reached significantly $(P<$ $0.05)$ higher germination percentages than ripe seeds. For these same accessions, the final germination percentage of ripe and unripe seeds presoaked for $24 \mathrm{~h}$ in distilled water (control seeds) ranged from $0 \%$ to $1 \%$. For ripe seeds, highly significant differences $(P<0.001)$ were found among the 21 accessions tested for seed water content, seed mass, and seed germination. Similarly, for unripe seeds highly significant differences $(P<0.001)$ were found for seed mass. However, no significant differences among accessions were found for seed water content $(P=0.0532)$ and final germination percentage $(P=0.0807)$.

\section{Effect of concentration of $\mathrm{GA}_{3}$ and putrescine on seed germination}

Table 7 shows the effect of several concentrations of $\mathrm{GA}_{3}$ and putrescine on the seed germination parameters (final germination percentage and MGT) of two $G$. lutea accessions. Presoaking with $\mathrm{GA}_{3}$ and putrescine did enhance final germination percentages in the two accessions tested. Significantly higher germinations than those of control (untreated seeds) were obtained with $\mathrm{GA}_{3}$ concentrations $\geq 10 \mathrm{mg} \cdot \mathrm{L}^{-1}$ (for both accessions) and with putrescine concentrations $\geq 50 \mathrm{mg} \cdot \mathrm{L}^{-1}$ (accession 41 ) and $\geq 100 \mathrm{mg} \cdot \mathrm{L}^{-1}$ (accession 52). For each concentration, applications of $\mathrm{GA}_{3}$ were always more effective than those of putrescine for increasing seed germination. Thus, $\mathrm{GA}_{3}$ concentrations higher than $100 \mathrm{mg} \cdot \mathrm{L}^{-1}$ increased the final germination percentages up to $90 \%$, while the highest germination reached with putrescine applications was $43 \%$ at a concentration of $250 \mathrm{mg} \cdot \mathrm{L}^{-1}$.

\section{Discussion}

Gentiana lutea seeds of all sampled populations showed 
Table 3. Effect of light conditions on the final germination percentage and mean germination time (MGT, days) of seeds from two Gentiana lutea accessions.

\begin{tabular}{lllllll}
\hline & & \multicolumn{2}{c}{ Germination $(\% \pm \mathrm{SE})$} & & \multicolumn{2}{c}{ MGT $($ days $\pm \mathrm{SE})$} \\
\cline { 3 - 4 } \cline { 6 - 7 } Accession & Light condition & Control & $\mathrm{GA}_{3}$ & & Control & $\mathrm{GA}_{3}$ \\
\hline 41 & Photoperiod & 0 & $91 \pm 0.00 \mathrm{a}$ & & $\mathrm{nc}$ & $21.20 \pm 0.71 \mathrm{a}$ \\
& Darkness & 0 & $97 \pm 0.00 \mathrm{a}$ & & $\mathrm{nc}$ & $22.00 \pm 0.49 \mathrm{a}$ \\
52 & Photoperiod & 0 & $95 \pm 3.53 \mathrm{a}$ & & $\mathrm{nc}$ & $17.90 \pm 0.92 \mathrm{a}$ \\
& Darkness & 0 & $96 \pm 2.48 \mathrm{a}$ & & $\mathrm{nc}$ & $23.05 \pm 0.18 \mathrm{a}$ \\
\hline
\end{tabular}

Note: nc, MGT value was not calculated when germination percentage was equal to or less than $5 \%$. Mean values followed by the same letters in a column per each population are not significantly different $(P>0.05)$ according to LSD test. Seeds were soaked for $24 \mathrm{~h}$ in distilled water (control) or in a gibberellic acid solution $\left(\mathrm{GA}_{3}, 1000 \mathrm{mg} \cdot \mathbf{L}^{-1}\right)$ before being germinated. Values are mean \pm standard error $(n=$ 4) after $75 \mathrm{~d}$ of seed incubation at $15^{\circ} \mathrm{C}$ under a 16 -h light photoperiod or constant darkness.

physiological dormancy. Germination of seeds presoaked for $24 \mathrm{~h}$ in distilled water (control seeds) was in the range of $0 \%-11 \%$ and germination was always increased by $\mathrm{GA}_{3}$. Soaking seeds in $1000 \mathrm{mg} \cdot \mathrm{L}^{-1} \mathrm{GA}_{3}$ for $24 \mathrm{~h}$ resulted in high germination. Thus, $\mathrm{GA}_{3}$-treated seeds reached final germination percentages at $15{ }^{\circ} \mathrm{C}$ equal or higher than $85 \%$ in 49 of 56 accessions ( $87.5 \%$ of accessions tested). These results are in accordance with those obtained by Struwe and Albert (2002) for several Gentiana species, Morgan et al. (1997) in G. cerina and $G$. corymbifera, and Bicknell (1984) in $G$ scabra. $\mathrm{GA}_{3}$ enhances seed germination in species exhibiting physiological or morphophysiological dormancy (Baskin and Baskin 1998; Xiaojie et al. 1999). In our study, G. lutea seeds imbibed water promptly and quickly during soaking. It only took $24 \mathrm{~h}$ for seeds of the two accessions tested to become fully imbibed (ca. 134\%-139\% of their initial seed mass, depending on the accession). They had a fully developed embryo that did not grow inside the seed prior to germination. Therefore, seeds of this species did not exhibit physical or morphological dormancy. The addition of $\mathrm{GA}_{3}$ was shown to be the most successful treatment for stimulating germination in $G$. lutea seeds. Dormancy break by $\mathrm{GA}_{3}$ is typical in seeds with nondeep physiological dormancy (Baskin and Baskin 1998). According to these results, it seems very plausible that $G$. lutea exhibits nondeep physiological dormancy according of the classification system proposed by Baskin and Baskin (2004). In conclusion, seeds of all sampled populations of $G$. lutea were physiologically dormant and required a $\mathrm{GA}_{3}$ pretreatment to germinate.

Germination of seeds presoaked in $\mathrm{GA}_{3}$ from the two accessions tested was higher than $75 \%$ at all incubation temperatures used (between $10^{\circ} \mathrm{C}$ and $25^{\circ} \mathrm{C}$ ). However, the highest germination percentage was recorded at $15^{\circ} \mathrm{C}$, although significant differences were not found. This species showed no preference for alternate vs. constant temperature regimes, in contrast with the germination behavior of several other wetland species (Kettenring and Galatowitsch 2007; Thompson and Grime 1983). Seeds from these two accessions germinated both under a 16-h light photoperiod and under complete darkness. It should be taken into account that germination under darkness was checked under green safe light and this light may trigger germination in some species (Baskin and Baskin 1979; Luna et al. 2004). However, in a previous trial (not reported here), we studied the effect of continuous darkness on $G$. lutea seed germination by checking only once after a 35-day period. We found that $\mathrm{GA}_{3}$ treated seeds reached high germination percentages both under darkness and photoperiod incubation. Therefore, temperature and light were not crucial factors for germination of $G$. lutea seeds. Yellow gentian seeds were able to germinate at a wide range of temperatures and under light or darkness provided that they were treated with $\mathrm{GA}_{3}$. The sites where G. lutea grows maintain high soil moisture content throughout the year. Therefore, once the gentian seeds have lost their dormancy, they will germinate in a wide range of temperatures, as similarly reported for many temperate climates species around the world (Baskin and Baskin 1998; Vandelook and Van Assche 2008). Since mountain ecosystems are typically subjected to a short growing season, this strategy could be claimed to ensure enough time for seedling establishment (Grime 2001; Körner 2003).

The germination of yellow gentian seeds was slow and progressive. The first seeds germinated, generally, between 8 and 10 days after sowing and seed germination occurred gradually over about 60 days. Germination of presoaked seeds in distilled water (control seeds) was very slow, with MGT values greater than 35 days. On the other hand, the germination of $\mathrm{GA}_{3}$-treated seeds was relatively slow, with MGT values greater than 13 days. A high germination speed increases the likelihood of rapid establishment in a habitat with intermittent precipitation. However, in the habitat where $G$. lutea grows the edaphic moisture is a parameter that remains more or less constant throughout the year. Therefore, soil moisture content will never be a limiting factor for seed germination and for seedling establishment in this species.

We found morphological (seed mass and seed water content) and physiological (seed germination) variability among $G$. lutea accessions. Intraspecific differences in final germination percentages were highly significant in Spanish populations of $G$. lutea. Populations from similar habitats may have different germination responses. These differences can arise from environmental variation during seed maturation and the effect of maternal genotype (Fenner 1991; Wulff 1995). Indeed, intraspecific variation in germination characteristics could be interpreted as one of the most important survival strategies for species growing under unpredictable environmental conditions (Kigel 1995). However, all sites where $G$. lutea grows have very similar environmental characteristics and they are very stable. For example, all these habitats maintain high soil moisture content throughout the year. On the other hand, it is well known that some mountain plants show high variation in germination behavior, which is not always attributed to the habitat characteristics (Chambers 1989; Giménez-Benavides et al. 2005). 
Table 4. Effect of moist chilling at $5{ }^{\circ} \mathrm{C}$ for 1 year on the final germination percentage of 35 Gentiana lutea accessions collected in 2008 (see Table 1).

\begin{tabular}{|c|c|c|c|c|c|c|}
\hline \multirow[b]{2}{*}{ Accession } & \multicolumn{3}{|l|}{ Control } & \multicolumn{3}{|l|}{$\mathrm{GA}_{3}$} \\
\hline & Nonchilled & Chilled & $P^{(1)}$ & Nonchilled & Chilled & $P^{(1)}$ \\
\hline 4 & 0 & 0 & ns & $65 \pm 4.95$ & $82 \pm 8.13$ & $\mathrm{~ns}$ \\
\hline 5 & $2 \pm 0.00$ & 0 & ns & $99 \pm 0.71$ & $98 \pm 1.06$ & ns \\
\hline 8 & $1 \pm 0.71$ & 0 & $\mathrm{~ns}$ & $98 \pm 1.41$ & $90 \pm 2.83$ & $\mathrm{~ns}$ \\
\hline 12 & 0 & 0 & ns & $87 \pm 2.12$ & $91 \pm 3.89$ & ns \\
\hline 15 & $6 \pm 1.41$ & 0 & $*$ & $92 \pm 1.41$ & $86 \pm 2.12$ & $\mathrm{~ns}$ \\
\hline 18 & $4 \pm 1.41$ & 0 & $\mathrm{~ns}$ & $98 \pm 1.41$ & $98 \pm 1.06$ & $\mathrm{~ns}$ \\
\hline 19 & $1 \pm 0.71$ & 0 & ns & $92 \pm 1.41$ & $94 \pm 3.89$ & ns \\
\hline 20 & $9 \pm 0.71$ & 0 & $* *$ & $95 \pm 2.12$ & $98 \pm 1.06$ & $\mathrm{~ns}$ \\
\hline 21 & $2 \pm 1.41$ & 0 & $\mathrm{~ns}$ & $89 \pm 2.12$ & $94 \pm 3.89$ & $\mathrm{~ns}$ \\
\hline 22 & $4 \pm 1.41$ & 0 & ns & $92 \pm 2.83$ & $75 \pm 1.06$ & $\mathrm{~ns}$ \\
\hline 23 & 0 & 0 & $\mathrm{~ns}$ & $83 \pm 4.95$ & $84 \pm 3.18$ & $\mathrm{~ns}$ \\
\hline 28 & $1 \pm 0.71$ & 0 & $\mathrm{~ns}$ & $90 \pm 1.41$ & $97 \pm 2.12$ & $\mathrm{~ns}$ \\
\hline 29 & 0 & 0 & ns & $93 \pm 2.12$ & $95 \pm 1.06$ & $\mathrm{~ns}$ \\
\hline 31 & $2 \pm 1.41$ & $1 \pm 0.99$ & $\mathrm{~ns}$ & $95 \pm 3.53$ & $94 \pm 2.12$ & $\mathrm{~ns}$ \\
\hline 32 & 0 & 0 & ns & $95 \pm 2.12$ & $90 \pm 4.95$ & $\mathrm{~ns}$ \\
\hline 34 & 0 & 0 & $\mathrm{~ns}$ & $91 \pm 2.12$ & $86 \pm 2.12$ & $\mathrm{~ns}$ \\
\hline 35 & $2 \pm 1.41$ & 0 & $\mathrm{~ns}$ & $91 \pm 0.70$ & $95 \pm 3.18$ & $\mathrm{~ns}$ \\
\hline 36 & $2 \pm 0.00$ & $7 \pm 5.06$ & ns & $91 \pm 0.70$ & $95 \pm 1.06$ & $\mathrm{~ns}$ \\
\hline 38 & 0 & 0 & $\mathrm{~ns}$ & $87 \pm 3.53$ & $81 \pm 5.30$ & $\mathrm{~ns}$ \\
\hline 39 & 0 & $13 \pm 7.07$ & $*$ & $89 \pm 4.95$ & $90 \pm 0.71$ & $\mathrm{~ns}$ \\
\hline 41 & 0 & 0 & $\mathrm{~ns}$ & $98 \pm 1.41$ & $95 \pm 1.06$ & $\mathrm{~ns}$ \\
\hline 42 & $2 \pm 1.41$ & $10 \pm 3.04$ & $*$ & $86 \pm 2.83$ & $93 \pm 4.94$ & $\mathrm{~ns}$ \\
\hline 43 & 0 & 0 & ns & $93 \pm 3.53$ & $83 \pm 4.24$ & ns \\
\hline 44 & 0 & 0 & ns & $81 \pm 3.53$ & $88 \pm 1.77$ & $\mathrm{~ns}$ \\
\hline 46 & 0 & 0 & $\mathrm{~ns}$ & $96 \pm 2.83$ & $93 \pm 4.94$ & $\mathrm{~ns}$ \\
\hline 47 & 0 & 0 & ns & $91 \pm 4.95$ & $93 \pm 4.60$ & $\mathrm{~ns}$ \\
\hline 48 & 0 & $1 \pm 0.99$ & $\mathrm{~ns}$ & $97 \pm 2.12$ & $98 \pm 1.06$ & $\mathrm{~ns}$ \\
\hline 49 & $8 \pm 4.24$ & 0 & ns & $99 \pm 0.71$ & $91 \pm 1.77$ & $\mathrm{~ns}$ \\
\hline 50 & $7 \pm 3.53$ & 0 & $*$ & $94 \pm 2.83$ & $95 \pm 3.18$ & $\mathrm{~ns}$ \\
\hline 51 & 0 & 0 & $\mathrm{~ns}$ & $97 \pm 2.12$ & $92 \pm 1.06$ & $\mathrm{~ns}$ \\
\hline 52 & $1 \pm 0.71$ & 0 & ns & $99 \pm 0.71$ & $95 \pm 1.06$ & ns \\
\hline 53 & $3 \pm 0.71$ & 0 & $*$ & $96 \pm 1.41$ & $97 \pm 0.00$ & $\mathrm{~ns}$ \\
\hline 54 & $7 \pm 0.71$ & $1 \pm 0.99$ & *** & $93 \pm 2.12$ & $93 \pm 2.83$ & $\mathrm{~ns}$ \\
\hline 55 & $11 \pm 4.95$ & $3 \pm 2.01$ & $*$ & $87 \pm 3.53$ & $95 \pm 3.18$ & $\mathrm{~ns}$ \\
\hline 56 & 0 & 0 & $\mathrm{~ns}$ & $93 \pm 2.12$ & $94 \pm 3.89$ & $\mathrm{~ns}$ \\
\hline$F$ value & 3.4308 & 2.3960 & - & 2.1281 & 1.2492 & - \\
\hline$P^{(2)}$ & 0.0002 & 0.0048 & - & 0.0124 & 0.2518 & - \\
\hline
\end{tabular}

Note: $P^{(I)}$, for each population and treatment (control or $\mathrm{GA}_{3}$ ) signifies significance level for nonchilled seeds versus chilled seeds $\left({ }^{*} P<0.01 ;{ }^{*} P<0.05\right.$; ns, not significant). $P^{(2)}$, for each column signifies differences among accessions. Seeds were soaked for $24 \mathrm{~h}$ in distilled water (control) or in a gibberellic acid solution $\left(\mathrm{GA}_{3}, 1000 \mathrm{mg} \cdot \mathrm{L}^{-1}\right)$ before being germinated. Values are mean \pm standard error $(n=2)$ after 75 days of seed incubation at $15{ }^{\circ} \mathrm{C}$ under a 16-h light photoperiod. Accessions are ranked by increasing altitude of collection site.

In some species there is a narrow correlation between seed mass and germination characteristics (see e.g., Milberg et al. 1996). Most studies have reported higher germination for heavier seeds compared to lighter seeds of the same species (Chiu et al. 2006; Moles et al. 2005). In our study a slightly positive correlation between seed mass and final germination percentage was found. Thus, the accessions with heaviest seeds generally reached highest final germination percentages. However, germination responses of $G$. lutea seeds did not correlate with the altitude of the collection site.

In alpine environments, a decrease in seed mass with increasing elevation has been detected among populations of a same species (Wirth et al. 2010). Unfavorable conditions (low temperatures and short growing seasons) for seed maturation at high elevations have been proposed to cause the decrease in seed mass with increasing elevation (Totland and Birks 1996; Wirth et al. 2010). On the contrary, Plues et al. (2005) found an increase in seed mass with increasing altitude between related species from low and high altitude but not among populations of individual species. In our study, we found no correlation of seed mass with altitude. These results are in accordance with those obtained by Plues et al. (2005) for four alpine species. Populations of $G$. lutea were sampled along an altitudinal range of 1396$1945 \mathrm{~m}$ a.s.l. (Table 3). Possibly, the altitudinal gradient covered (ca. $550 \mathrm{~m}$ ) was not sufficiently wide to detect 
Table 5. Effect of moist chilling at $5{ }^{\circ} \mathrm{C}$ for 1 year on the mean germination time (MGT, days) of 35 Gentiana lutea accessions collected in 2008 (see Table 1).

\begin{tabular}{|c|c|c|c|c|}
\hline \multirow[b]{2}{*}{ Accession } & \multicolumn{2}{|l|}{ Control } & \multicolumn{2}{|l|}{$\mathrm{GA}_{3}$} \\
\hline & Nonchilled & Chilled & Nonchilled & Chilled \\
\hline 4 & nc & nc & $22.95 \pm 0.60 \mathrm{a}$ & $30.65 \pm 2.37 \mathrm{a}$ \\
\hline 5 & $\mathrm{nc}$ & $\mathrm{nc}$ & $20.20 \pm 0.57 \mathrm{a}$ & $35.35 \pm 1.73 b$ \\
\hline 8 & $\mathrm{nc}$ & $\mathrm{nc}$ & $22.50 \pm 1.41 \mathrm{a}$ & $29.35 \pm 2.37 \mathrm{a}$ \\
\hline 12 & $\mathrm{nc}$ & nc & $20.15 \pm 1.10 \mathrm{a}$ & $27.95 \pm 0.74 a$ \\
\hline 15 & $51.00 \pm 8.64 \mathrm{a}$ & $\mathrm{nc}$ & $20.45 \pm 0.74 a$ & $35.60 \pm 1.27 \mathrm{a}$ \\
\hline 18 & $\mathrm{nc}$ & $\mathrm{nc}$ & $14.20 \pm 0.21 \mathrm{a}$ & $17.75 \pm 2.23 \mathrm{a}$ \\
\hline 19 & $\mathrm{nc}$ & $\mathrm{nc}$ & $18.15 \pm 0.74 a$ & $22.00 \pm 1.34 \mathrm{a}$ \\
\hline 20 & $55.50 \pm 2.88 \mathrm{c}$ & $\mathrm{nc}$ & $17.95 \pm 0.46 \mathrm{a}$ & $28.45 \pm 1.24 b$ \\
\hline 21 & $\mathrm{nc}$ & $\mathrm{nc}$ & $20.30 \pm 0.21 \mathrm{a}$ & $21.90 \pm 1.48 \mathrm{a}$ \\
\hline 22 & $\mathrm{nc}$ & nc & $23.25 \pm 0.74 a$ & $26.55 \pm 3.00 \mathrm{a}$ \\
\hline 23 & $\mathrm{nc}$ & $\mathrm{nc}$ & $19.40 \pm 0.07 \mathrm{a}$ & $26.45 \pm 0.32 b$ \\
\hline 28 & $\mathrm{nc}$ & $\mathrm{ne}$ & $19.30 \pm 0.35 \mathrm{a}$ & $20.10 \pm 0.14 \mathrm{a}$ \\
\hline 29 & $\mathrm{nc}$ & $\mathrm{nc}$ & $20.60 \pm 0.78 \mathrm{a}$ & $24.30 \pm 0.21 \mathrm{a}$ \\
\hline 31 & $\mathrm{nc}$ & ne & $17.25 \pm 0.39 \mathrm{a}$ & $21.40 \pm 0.57 \mathrm{a}$ \\
\hline 32 & $\mathrm{nc}$ & ne & $17.40 \pm 0.85 a$ & $24.40 \pm 0.14 b$ \\
\hline 34 & $\mathrm{nc}$ & $\mathrm{nc}$ & $21.70 \pm 0.50 \mathrm{a}$ & $29.10 \pm 0.64 b$ \\
\hline 35 & $\mathrm{nc}$ & nc & $16.05 \pm 0.53 \mathrm{a}$ & $22.55 \pm 2.72 \mathrm{a}$ \\
\hline 36 & $\mathrm{nc}$ & $32.00 \pm 0.00 \mathrm{~b}$ & $22.20 \pm 0.99 \mathrm{a}$ & $30.30 \pm 0.64 b$ \\
\hline 38 & $\mathrm{nc}$ & nc & $18.60 \pm 0.49 \mathrm{a}$ & $34.65 \pm 0.81 b$ \\
\hline 39 & $\mathrm{nc}$ & $28.60 \pm 0.42 b$ & $17.10 \pm 0.35 \mathrm{a}$ & $27.95 \pm 1.38 \mathrm{~b}$ \\
\hline 41 & $\mathrm{nc}$ & $\mathrm{nc}$ & $17.50 \pm 0.64 \mathrm{a}$ & $29.65 \pm 1.52 b$ \\
\hline 42 & $\mathrm{nc}$ & $29.40 \pm 6.65 a$ & $20.30 \pm 0.42 \mathrm{a}$ & $26.15 \pm 1.10 \mathrm{a}$ \\
\hline 43 & $\mathrm{nc}$ & nc & $21.55 \pm 0.11 \mathrm{a}$ & $27.50 \pm 0.14 b$ \\
\hline 44 & $\mathrm{nc}$ & $\mathrm{nc}$ & $15.55 \pm 0.39 \mathrm{a}$ & $24.00 \pm 2.05 \mathrm{a}$ \\
\hline 46 & $\mathrm{nc}$ & $\mathrm{nc}$ & $16.05 \pm 0.18 \mathrm{a}$ & $24.55 \pm 1.45 \mathrm{a}$ \\
\hline 47 & $\mathrm{nc}$ & $\mathrm{nc}$ & $16.80 \pm 0.35 a$ & $28.00 \pm 0.07 \mathrm{~b}$ \\
\hline 48 & $\mathrm{nc}$ & $\mathrm{nc}$ & $15.90 \pm 0.21 \mathrm{a}$ & $18.40 \pm 1.27 \mathrm{a}$ \\
\hline 49 & $52.30 \pm 4.69 b$ & $\mathrm{nc}$ & $16.37 \pm 0.42 \mathrm{a}$ & $27.50 \pm 0.07 \mathrm{a}$ \\
\hline 50 & $35.25 \pm 7.68 \mathrm{a}$ & $\mathrm{nc}$ & $16.30 \pm 1.20 \mathrm{a}$ & $18.65 \pm 1.58 \mathrm{a}$ \\
\hline 51 & nc & $\mathrm{nc}$ & $14.80 \pm 0.07 \mathrm{a}$ & $23.00 \pm 0.28 b$ \\
\hline 52 & $\mathrm{nc}$ & nc & $16.30 \pm 0.28 \mathrm{a}$ & $17.90 \pm 0.21 \mathrm{a}$ \\
\hline 53 & $\mathrm{nc}$ & $\mathrm{nc}$ & $17.00 \pm 0.14 \mathrm{a}$ & $21.75 \pm 0.39 b$ \\
\hline 54 & $39.25 \pm 11.96 \mathrm{a}$ & $\mathrm{nc}$ & $15.77 \pm 0.05 \mathrm{a}$ & $23.50 \pm 0.28 \mathrm{a}$ \\
\hline 55 & $42.82 \pm 4.95 b$ & $\mathrm{nc}$ & $17.32 \pm 2.46 \mathrm{a}$ & $22.25 \pm 0.95 \mathrm{a}$ \\
\hline 56 & $\mathrm{nc}$ & $\mathrm{nc}$ & $16.75 \pm 0.03 \mathrm{a}$ & $16.80 \pm 0.49 \mathrm{a}$ \\
\hline$F$ value & 0.3865 & 0.1069 & 5.9138 & 6.7467 \\
\hline$P$ & 0.8420 & 0.9019 & 0.0000 & 0.0000 \\
\hline
\end{tabular}

Note: nc, MGT value was not calculated when germination percentage (see Table 4) was equal to or less than $5 \%$. Mean values followed by the same letter in a row are not significantly different $(P>0.05)$ according to LSD test. $P$, for each column signifies differences among accessions. Seeds were soaked for $24 \mathrm{~h}$ in distilled water (control) or in a gibberellic acid solution $\left(\mathrm{GA}_{3}\right.$, $\left.1000 \mathrm{mg} \cdot \mathrm{L}^{-1}\right)$ before being germinated. Values are mean \pm standard error $(n=2)$ after 75 days of seed incubation at $15{ }^{\circ} \mathrm{C}$ under a 16-h light photoperiod. Accessions are ranked by increasing altitude of collection site.

any correlation between seed mass and altitude of collection site.

Moist chilling did not significantly increase the final germination percentages over the nonchilled seeds of the different $G$. lutea accessions tested. These results do not agree with those obtained by Favarger (1953), who reported that cold stratification enhanced seed germination of $G$. lutea. In our study, chilling for 1 week and 1, 3, 6, and 12 months was completely ineffective in promoting germination and even the chilled seeds germinated more slowly (as expressed by MGT) than nonchilled seeds of the same accession.

Polyamines have been implicated in various plant growth and developmental processes, such as promotion of seed germination (Matilla 1996). Putrescine is a polyamine that is used as a plant growth regulator (Zeid and Shedeed 2006). We hypothesized that putrescine could break seed dormancy of $G$. lutea because previous studies have reported that this polyamine promotes seed germination in several species (Korkmaz et al. 2005; Matilla 1996; Zeid and Shedeed 2006). The effect of putrescine is similar to that of gibberellic acid, which promotes embryo maturation (Flores et al. 2008). However, putrescine in our study did not replace the effect of $\mathrm{GA}_{3}$ in promoting seed germination of $G$. lutea. Thus, $\mathrm{GA}_{3}$ improved seed germination by dou- 
Table 6. Seed water content, seed mass, and final germination percentage of 21 Gentiana lutea accessions collected in 2009 (see Table 1).

\begin{tabular}{|c|c|c|c|c|c|c|c|c|c|}
\hline \multirow[b]{2}{*}{ Accession } & \multicolumn{3}{|c|}{ Seed water content $(\% \pm \mathrm{SE})$} & \multicolumn{3}{|c|}{ Mass per 100 seeds $(\mathrm{mg} \pm \mathrm{SE})$} & \multicolumn{2}{|c|}{ Germination $(\% \pm \mathrm{SE})$} & \multirow[b]{2}{*}{$P^{(1)}$} \\
\hline & Ripe seeds & Unripe seeds & $P^{(1)}$ & Ripe seeds & Unripe seeds & $P^{(1)}$ & Ripe seeds & Unripe seeds & \\
\hline 1 & $4.69 \pm 0.06$ & $4.91 \pm 0.06$ & ns & $101.35 \pm 2.65$ & $109.90 \pm 1.34$ & $\mathrm{~ns}$ & $94 \pm 2.12$ & $89 \pm 3.53$ & ns \\
\hline 2 & $5.38 \pm 0.04$ & $5.57 \pm 0.26$ & $\mathrm{~ns}$ & $109.85 \pm 3.85$ & $124.45 \pm 4.84$ & $\mathrm{~ns}$ & $86 \pm 2.47$ & $85 \pm 0.71$ & $\mathrm{~ns}$ \\
\hline 3 & $5.74 \pm 0.07$ & $6.01 \pm 0.01$ & $\mathrm{~ns}$ & $89.00 \pm 0.35$ & $99.20 \pm 0.00$ & $* *$ & $85 \pm 0.35$ & $91 \pm 0.00$ & $* *$ \\
\hline 6 & $5.43 \pm 0.08$ & $5.67 \pm 0.00$ & $\mathrm{~ns}$ & $133.00 \pm 3.18$ & $147.50 \pm 3.39$ & $\mathrm{~ns}$ & $98 \pm 1.06$ & $97 \pm 2.12$ & $\mathrm{~ns}$ \\
\hline 7 & $4.90 \pm 0.13$ & $5.02 \pm 0.13$ & ns & $91.95 \pm 3.99$ & $94.40 \pm 1.06$ & ns & $94 \pm 0.00$ & $95 \pm 0.35$ & ns \\
\hline 9 & $5.39 \pm 0.19$ & $5.69 \pm 0.35$ & $\mathrm{~ns}$ & $115.75 \pm 1.87$ & $123.60 \pm 1.70$ & $\mathrm{~ns}$ & $90 \pm 0.35$ & $88 \pm 1.06$ & $\mathrm{~ns}$ \\
\hline 10 & $4.86 \pm 0.15$ & $5.30 \pm 0.00$ & $\mathrm{~ns}$ & $110.30 \pm 1.56$ & $115.90 \pm 0.71$ & $\mathrm{~ns}$ & $88 \pm 2.83$ & $85 \pm 4.24$ & $\mathrm{~ns}$ \\
\hline 11 & $5.08 \pm 0.09$ & $5.16 \pm 0.00$ & $\mathrm{~ns}$ & $134.50 \pm 2.54$ & $155.15 \pm 1.59$ & $*$ & $98 \pm 1.06$ & $93 \pm 1.41$ & $\mathrm{~ns}$ \\
\hline 13 & $5.18 \pm 0.02$ & $5.92 \pm 0.13$ & $\mathrm{~ns}$ & $126.35 \pm 4.21$ & $127.25 \pm 4.98$ & $\mathrm{~ns}$ & $66 \pm 1.41$ & $94 \pm 1.77$ & $*$ \\
\hline 14 & $5.75 \pm 0.07$ & $5.77 \pm 0.07$ & $\mathrm{~ns}$ & $109.60 \pm 1.34$ & $114.70 \pm 1.91$ & $\mathrm{~ns}$ & $95 \pm 3.18$ & $93 \pm 1.77$ & $\mathrm{~ns}$ \\
\hline 16 & $5.17 \pm 0.19$ & $5.89 \pm 0.49$ & $\mathrm{~ns}$ & $150.00 \pm 2.12$ & $141.40 \pm 7.49$ & $\mathrm{~ns}$ & $93 \pm 4.95$ & $94 \pm 2.12$ & $\mathrm{~ns}$ \\
\hline 17 & $4.60 \pm 0.09$ & $5.38 \pm 0.06$ & $*$ & $105.35 \pm 4.21$ & $111.50 \pm 0.14$ & $* *$ & $88 \pm 3.53$ & $95 \pm 1.41$ & $\mathrm{~ns}$ \\
\hline 24 & $5.24 \pm 0.00$ & $5.65 \pm 0.17$ & $\mathrm{~ns}$ & $85.85 \pm 1.38$ & $88.95 \pm 1.52$ & $\mathrm{~ns}$ & $90 \pm 1.77$ & $97 \pm 0.00$ & $\mathrm{~ns}$ \\
\hline 25 & $5.88 \pm 0.06$ & $5.94 \pm 0.16$ & $\mathrm{~ns}$ & $134.40 \pm 0.21$ & $166.70 \pm 0.35$ & $* * *$ & $80 \pm 2.12$ & $95 \pm 1.06$ & $*$ \\
\hline 26 & $5.47 \pm 0.07$ & $5.65 \pm 0.08$ & $\mathrm{~ns}$ & $84.95 \pm 0.53$ & $109.65 \pm 0.95$ & $* *$ & $85 \pm 1.77$ & $87 \pm 2.83$ & $\mathrm{~ns}$ \\
\hline 27 & $5.85 \pm 0.11$ & $6.43 \pm 0.20$ & $\mathrm{~ns}$ & $74.20 \pm 1.98$ & $99.05 \pm 1.73$ & $*$ & $74 \pm 2.83$ & $89 \pm 1.06$ & $\mathrm{~ns}$ \\
\hline 30 & $5.78 \pm 0.07$ & $5.89 \pm 0.05$ & $\mathrm{~ns}$ & $84.70 \pm 1.48$ & $94.20 \pm 2.69$ & $\mathrm{~ns}$ & $91 \pm 2.47$ & $83 \pm 2.12$ & $\mathrm{~ns}$ \\
\hline 33 & $5.55 \pm 0.01$ & $5.57 \pm 0.06$ & $\mathrm{~ns}$ & $85.30 \pm 3.18$ & $115.75 \pm 1.87$ & $*$ & $61 \pm 2.12$ & $89 \pm 4.60$ & $\mathrm{~ns}$ \\
\hline 37 & $5.41 \pm 0.24$ & $5.71 \pm 0.13$ & $\mathrm{~ns}$ & $128.75 \pm 1.24$ & $132.90 \pm 0.64$ & $\mathrm{~ns}$ & $96 \pm 2.47$ & $96 \pm 2.83$ & $\mathrm{~ns}$ \\
\hline 40 & $5.34 \pm 0.17$ & $5.69 \pm 0.14$ & $\mathrm{~ns}$ & $100.00 \pm 2.40$ & $107.70 \pm 2.97$ & $\mathrm{~ns}$ & $86 \pm 0.71$ & $95 \pm 1.06$ & $*$ \\
\hline 45 & $5.40 \pm 0.01$ & $5.54 \pm 0.07$ & $\mathrm{~ns}$ & $98.20 \pm 1.56$ & $112.80 \pm 0.42$ & $*$ & $94 \pm 0.00$ & $90 \pm 0.71$ & $\mathrm{~ns}$ \\
\hline$F$ value & 6.8601 & 2.0672 & - & 40.3654 & 28.9619 & - & 4.2536 & 1.8742 & - \\
\hline$P^{(2)}$ & 0.0000 & 0.0532 & - & 0.0000 & 0.0000 & - & 0.0009 & 0.0807 & - \\
\hline
\end{tabular}

Note: $P^{(l)}$, for each population and parameter signifies significance level for ripe seeds versus unripe seeds $(* * *, P<0.001 ; * *, P<0.01 ; *, P<0.05$; ns, not significant). $P^{(2)}$, for each column signifies differences among accessions. For each accession, fully ripe seeds (ripe seeds) and less ripe seeds (unripe seeds) were collected. Seeds were soaked for $24 \mathrm{~h}$ in a gibberellic acid solution $\left(\mathrm{GA}_{3}, 1000 \mathrm{mg} \cdot \mathrm{L}^{-1}\right.$ ) before being germinated. Accessions are ranked by increasing altitude of collection site. Soaking ripe and unripe seeds in distilled water for $24 \mathrm{~h}$ (control) resulted in 0\% final germination percentage (data not shown). Germination percentage values are mean \pm standard error $(n=2)$ after 75 days of seed incubation at $15^{\circ} \mathrm{C}$ under a 16 -h light photoperiod.

Table 7. Effect of presoaking for $24 \mathrm{~h}$ in distilled water (control) and gibberellic acid $\left(\mathrm{GA}_{3}\right)$ or putrescine solutions on the final germination percentage and mean germination time (MGT, days) of seeds from two Gentiana lutea accessions.

\begin{tabular}{|c|c|c|c|c|c|}
\hline \multirow[b]{2}{*}{ Treatment } & \multirow{2}{*}{$\begin{array}{l}\text { Concentration } \\
\left(\mathrm{mg} \cdot \mathrm{L}^{-1}\right)\end{array}$} & \multicolumn{2}{|c|}{ Germination $(\% \pm \mathrm{SE})$} & \multicolumn{2}{|c|}{ MGT (days \pm SE) } \\
\hline & & Accession 41 & Accession 52 & Accession 41 & Accession 52 \\
\hline \multirow[t]{7}{*}{$\mathrm{GA}_{3}$} & Control & $0 \mathrm{a}$ & $0 \mathrm{a}$ & $\mathrm{nc}$ & $\mathrm{nc}$ \\
\hline & 10 & $27 \pm 1.06 \mathrm{~b}$ & $21 \pm 5.30 \mathrm{~b}$ & $50.05 \pm 1.17 \mathrm{c}$ & $39.10 \pm 6.01 b$ \\
\hline & 50 & $83 \pm 5.30 \mathrm{c}$ & $60 \pm 0.00 \mathrm{c}$ & $27.05 \pm 1.59 \mathrm{~b}$ & $24.30 \pm 1.27 \mathrm{a}$ \\
\hline & 100 & $95 \pm 1.06 \mathrm{c}$ & $94 \pm 0.00 \mathrm{~d}$ & $16.65 \pm 0.81 \mathrm{a}$ & $18.15 \pm 0.11 \mathrm{a}$ \\
\hline & 250 & $97 \pm 2.12 \mathrm{c}$ & $95 \pm 3.18 \mathrm{~d}$ & $18.10 \pm 1.06 \mathrm{a}$ & $17.40 \pm 0.07 \mathrm{a}$ \\
\hline & 500 & $98 \pm 1.06 \mathrm{c}$ & $88 \pm 3.89 \mathrm{~d}$ & $20.35 \pm 0.67 \mathrm{a}$ & $18.55 \pm 0.39 a$ \\
\hline & 1000 & $99 \pm 0.87 \mathrm{c}$ & $94 \pm 2.24 d$ & $17.72 \pm 0.74 \mathrm{a}$ & $15.85 \pm 0.47 \mathrm{a}$ \\
\hline \multirow[t]{7}{*}{ Putrescine } & Control & $0 \mathrm{a}$ & $0 \mathrm{a}$ & $\mathrm{nc}$ & $\mathrm{nc}$ \\
\hline & 10 & $0 \mathrm{a}$ & $0 \mathrm{a}$ & $\mathrm{nc}$ & $\mathrm{nc}$ \\
\hline & 50 & $11 \pm 1.77 \mathrm{~b}$ & $0 \mathrm{a}$ & $26.00 \pm 0.00 \mathrm{a}$ & $\mathrm{nc}$ \\
\hline & 100 & $12 \pm 1.06 \mathrm{~b}$ & $6 \pm 0.00 \mathrm{~b}$ & $45.60 \pm 1.13 b$ & $20.75 \pm 0.88 a$ \\
\hline & 250 & $43 \pm 4.24 c$ & $19 \pm 7.07 \mathrm{~b}$ & $46.35 \pm 1.59 b$ & $39.50 \pm 2.47 \mathrm{a}$ \\
\hline & 500 & $36 \pm 4.95 \mathrm{c}$ & $16 \pm 4.95 b$ & $48.10 \pm 2.59 \mathrm{~b}$ & $37.45 \pm 1.02 \mathrm{a}$ \\
\hline & 1000 & $6 \pm 2.24 b$ & $8 \pm 1.41 b$ & $52.10 \pm 1.34 \mathrm{~b}$ & $40.30 \pm 5.80 \mathrm{a}$ \\
\hline
\end{tabular}

\footnotetext{
Note: nc, MGT value was not calculated when germination percentage was equal to or less than $5 \%$. Mean values followed by the same letters in a column per treatment $\left(\mathrm{GA}_{3}\right.$ or putrescine) are not significantly different $(P>0.05)$ according to LSD test. Values are mean \pm standard error $(n=4)$ after 75 days of seed incubation at $15^{\circ} \mathrm{C}$ under a $16-\mathrm{h}$ light photoperiod.
}

bling or even quintupling (depending on the accession and concentration) the final germination percentage, in comparison with putrescine. Similar results have been reported by
Flores et al. (2008), who found that putrescine did not improve the seed germination of two cacti species. On the other hand, the final germination percentages achieved for 
concentrations of $\mathrm{GA}_{3}$ ranging from 100 to $1000 \mathrm{mg} \cdot \mathrm{L}^{-1}$ were very similar.

Our data provide useful information in germination protocols for ex situ propagation of $G$. lutea, for example seed soaking for $24 \mathrm{~h}$ in $250 \mathrm{mg} \cdot \mathrm{L}^{-1} \mathrm{GA}_{3}$ before sowing and then seed incubation at $15{ }^{\circ} \mathrm{C}$ under photoperiod conditions may be suitable. Physiological dormancy was detected in seeds from all sampled populations of $G$. lutea and it was broken easily by $\mathrm{GA}_{3}$ pretreatments. However, moist chilling did not enhance the germination percentage. In addition, seeds belonging to different populations of $G$. lutea showed a considerable degree of physiological (final germination percentage under controlled conditions) and morphological (seed mass and seed water content) variability, which would be relevant when conserving seeds from multiple origins. To the best of our knowledge, this is the first report on morphological and physiological variability of $G$. lutea seeds.

\section{Acknowledgements}

We wish to thank Marta Huertas for her help with this work.

\section{References}

Akhalkatsi, M., and Wagner, J. 1997. Comparative embryology of three Gentianaceae species from the Central Caucasus and the European Alps. Plant Syst. Evol. 204(1-2): 39-48. doi:10.1007/ BF00982530.

Baskin, J.M., and Baskin, C.C. 1979. Promotion of germination of Stellaria media seeds by light from a green safe lamp. New Phytol. 82(2): 381-383. doi:10.1111/j.1469-8137.1979.tb02664.x.

Baskin, C.C., and Baskin, J.M. 1998. Seeds: ecology, biogeography, and evolution of dormancy and germination. Academic Press, San Diego, California.

Baskin, J.M., and Baskin, C.C. 2004. A classification system for seed dormancy. Seed Sci. Res. 14(01): 1-16. doi:10.1079/SSR2003150.

Baskin, C.C., and Baskin, J.M. 2005. Underdeveloped embryos in dwarf seeds and implications for assignment to dormancy class. Seed Sci. Res. 15(4): 357-360. doi:10.1079/SSR2005224.

Bettencourt, M. 1998. Medicinal and aromatic plants of the Mediterranean. IPGRI Newsletter for Europe, 13: 10.

Bewley, J.D., and Black, M. 1994. Seeds. Physiology of development and germination. Plenum Press, New York.

Bicknell, R.A. 1984. Seed propagation of Gentiana scabra. Proceeding of the International Plant Propagators Society, Vol. 34. pp. $396-401$.

Cerabolini, B., Ceriani, R.M., Caccianiga, M., De Andreis, R., and Raimondi, B. 2003. Seed size, shape and persistence in soil: a test on Italian flora from Alps to Mediterranean coasts. Seed Sci. Res. 13: 75-85. doi:10.1079/SSR2002126.

Chambers, J.C. 1989. Seed viability of alpine species: variability within and among years. J. Range Manage. 42(4): 304-308. doi: $10.2307 / 3899499$.

Chiu, K.J., Chuang, S.J., and Sung, J.M. 2006. Both anti-oxidation and lipid-carbohydrate conversion enhancement are involved in priming-improved emergence of Echinaceae purpurea seeds that differ in size. Sci. Hortic. (Amsterdam), 108(2): 220-226. doi:10. 1016/j.scienta.2006.01.019.

Ellis, R.H., and Roberts, E.H. 1981. The quantification of ageing and survival in orthodox seeds. Seed Sci. Technol. 9: 373-409.

Favarger, C. 1953. Sur la germination des gentianes. Phyton, 4: 275 289.

Fenner, M. 1991. The effects of the parent environment on seed germinability. Seed Sci. Res. 1(02): 75-84. doi:10.1017/ S0960258500000696.

Flores, J., Jurado, E., and Jiménez-Bremont, J.F. 2008. Breaking seed dormancy in specially protected Turbinicarpus lophophoroides and Turbinicarpus pseudopectinatus (Cactaceae). Plant Species Biol. 23(1): 43 -46. doi:10.1111/j. 1442-1984.2008.00206.x.

Giménez-Benavides, L., Escudero, A., and Pérez-García, F. 2005. Seed germination of high mountain Mediterranean species: altitudinal, interpopulation and interannual variability. Ecol. Res. 20(4): 433-444. doi:10.1007/s11284-005-0059-4.

Grime, J.P. 2001. Plant strategies, vegetation process, and ecosystems properties. John Wiley and Sons Ltd., Chichester.

ISTA 2003. International rules for seed testing. The International Seed Testing Association, Bassersdorf.

IUCN. 2010. Guidelines for using the IUCN Red List Categories and Criteria. Version 8.1. Prepared by the Standards and Petitions Subcommittee in March 2010. http://intranet.iucn.org/webfiles/ doc/SSC/RedList/RedListGuidelines.pdf. Accessed 4 September 2011 .

Kettenring, K.M., and Galatowitsch, S.M. 2007. Temperature requirements for dormancy break and seed germination very greatly among 14 wetland Carex species. Aquat. Bot. 87(3): 209220. doi:10.1016/j.aquabot.2007.06.003.

Kigel, J. 1995. Seed germination in arid and semiarid regions. In Seed development and germination. Edited by J. Kigel and G. Galili. Marcel Dekker, New York. pp. 645-699.

Korkmaz, A., Ozbay, N., Tiryaki, I., and Nas, M.N. 2005. Combining priming and plant growth regulators improves muskmelon germination and emergence at low temperatures. Eur. J. Hortic. Sci. 70: 29-34.

Körner, C. 2003. Alpine plant life: Functional plant ecology of high mountain ecosystems, 2nd ed. Springer, Berlin-Heidelberg.

Lorite, J., Ruiz-Girela, M., and Castro, J. 2007. Patterns of seed germination in Mediterranean mountains: study on 37 endemic or rare species from Sierra Nevada, SE Spain. Candollea, 62: 5-16.

Luna, B., Pérez, B., Fernández-González, F., and Moreno, J.M. 2004. Sensivity to green safelight of 12 Mediterranean species. Seed Sci. Technol. 32: 113-117.

Matilla, A.J. 1996. Polyamines and seed germination. Seed Sci. Res. 6(03): 81-93. doi:10.1017/S096025850000310X.

Mikuła, A., and Rybczyński, J.J. 2001. Somatic embryogenesis of Gentiana genus I. The effect of the preculture treatment and primary explant origin on somatic embryogenesis of Gentiana cruciata (L.), G. pannonica (Scop.), and G. tibetica (King). Acta Physiol. Plant. 23(1): 15-25. doi:10.1007/s11738-001-0017-x.

Milberg, P., Andersson, C., Elfverson, C., and Regnér, S. 1996. Germination characteristics of seeds differing in mass. Seed Sci. Res. 6(04): 191-197. doi:10.1017/S0960258500003251.

Moles, A.T., Ackerly, D.D., Webb, C.O., Tweddle, J.C., Dickie, J.B., and Westoby, M. 2005. A brief history of seed size. Science, 307(5709): 576-580. doi:10.1126/science.1104863. PMID 15681384 .

Momčilović, I., Grubišić, D., and Nešković, M. 1997. Micropropagation of four Gentiana species ( $G$. lutea, G. cruciata, G. purpurea and $G$. acaulis). Plant Cell Tiss. Org. Cult. 49(2): 141-144. doi:10. 1023/A:1005810430339.

Morgan, E.R., Butler, M.R., and Bicknell, R.A. 1997. In vitro propagation of Gentiana cerina and Gentiana corymbifera. N.Z. J. Crop Hortic. Sci. 25(1): 1-8. doi:10.1080/01140671.1997. 9513981.

Pluess, A.R., Schütz, W., and Stöcklin, J. 2005. Seed weight increases with altitude in the Swiss Alps between related species but not among populations of individual species. Oecologia (Berl.), 144(1): 55-61. doi:10.1007/s00442-005-0047-y. 
Raina, R., Behera, M.C., Chand, R., and Sharma, Y. 2003. Reproductive biology of Gentiana kurroo Royle. Curr. Sci. 85: $667-670$.

Schwienbacher, E., Navarro-Cano, J.A., Neuner, G., and Erschbamer, B. 2011. Seed dormancy in alpine species. Flora, 206(10): 845856. doi:10.1016/j.flora.2011.05.001.

Simpson, M.J.A., and Webb, C.J. 1980. Germination in some New Zealand species of Gentiana: a preliminary report. N.Z. J. Bot. 18(4): 495-501. doi:10.1080/0028825X.1980.10425172.

Struwe, L., and Albert, V.A. 2002. Gentianaceae: systematics and natural history. Cambridge University Press, Cambridge.

Thompson, K., and Grime, J.P. 1983. A comparative study of germination responses to diurnally-fluctuating temperatures. $\mathbf{J}$. Appl. Ecol. 20(1): 141-146. doi:10.2307/2403382.

Thompson, K., Bakker, J.P., and Bekker, R.M. 1997. The soil seed banks of North West Europe: methodology, density and longevity. Cambridge University Press, Cambridge.

Threadgill, P.F., Baskin, J.M., and Baskin, C.C. 1981. Dormancy in seeds of Frasera caroliniensis (Gentianaceae). Am. J. Bot. 68(1): 80-86. doi:10.2307/2442994.

Totland, Ø., and Birks, H.J.B. 1996. Factors influencing inter- population variation in Ranunculus acris seed population in an alpine area of southwestern Norway. Ecography, 19: 269-278.

Vandelook, F., and Van Assche, J.A. 2008. Temperature requirements for seed germination and seedling development determine timing of seedling emergence of three monocotyledonous temperate forest spring geophytes. Ann. Bot. (Lond.), 102(5): 865-875. doi:10. 1093/aob/men165. PMID:18757880.

Wirth, L.R., Graf, R., Gugerli, F., Landergott, U., and Holderegger, R. 2010. Between-year variation in seed weights across altitudes in the high-alpine plant Eritrichum nanum. Plant Ecol. 207(2): 227231. doi:10.1007/s11258-009-9667-3.

Wulff, R.D. 1995. Environmental maternal effects and seed quality and germination. In Seed development and germination. Edited by J. Kigel, and G. Galili. Marcel Dekker, New York. pp. 491-505.

Xiaojie, L., Baskin, J.M., and Baskin, C.C. 1999. Physiological dormancy and germination requirements of seeds of several North American Rhus species (Anacardiaceae). Seed Sci. Res. 9: 237245.

Zeid, I.M., and Shedeed, Z.A. 2006. Response of alfalfa to putrescine treatment under drought stress. Biol. Plant. 50(4): 635-640. doi:10.1007/s10535-006-0099-9. 